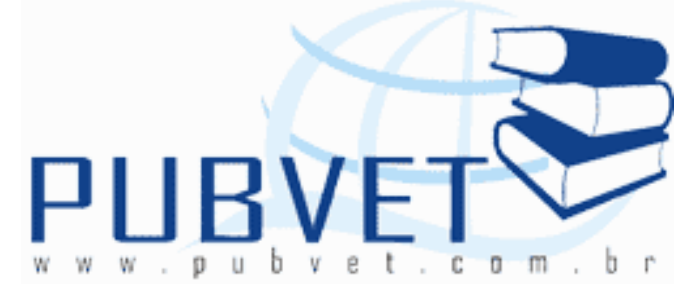

PUBVET, Publicações em Medicina Veterinária e Zootecnia.

\title{
Nutritional quality and safety assessment of ingredients and feed given to pregnant swine and piglets
}

\author{
Janaina Nones, Marcelina Bottoni Horn, Rafael Luchtenberg, Jader Nones, \\ Vildes Maria Scussel
}

Laboratory of Mycotoxicology and Food Contaminants - LABMICO. Department of Food Science and Technology. Center for Agricultural Sciences, Federal University of Santa Catarina, Rod Admar Gonzaga 1346, Itacorubi, Florianópolis, SC, Brazil.

\section{Abstract}

The assessment of the nutritional composition and quality of feed is of fundamental importance, as feed represents a large percentage of animal production cost. Changes in feed composition can alter metabolisms, reduce digestive capacity and growth, hence affecting the production performance and profits which are more critical in smaller swine farms. In this paper we report on an evaluation of the nutritional quality [proteins, lipids, carbohydrates, fibre, calcium ( $\mathrm{Ca}$ ) and phosphorus $(\mathrm{P})$ ] and safety [mycotoxins, moisture content $(\mathrm{mc})$ and water activity $\left(a_{\mathrm{w}}\right)$ ] of feed ingredients and final products in pregnant swine (gilts/sows) and off-spring (piglets) from a small production farm in Southern Brazil. From the nutrition quality data obtained, feed ingredients such as soybean meal, rice meal and corn presented protein average content of $46.35 \%, 13.94 \%$ and $8.88 \%$, respectively. As far as anti- 
nutritional factors are concerned, the urease level in the soybean meal used for swine feed production was of $0.03 \%$ (0.01 to 0.09 ). For the two different swine formulations analysed, the fibre values obtained were $1.74 \%$ and $2.14 \%$ for piglet and pregnancy feed, respectively. The $\mathrm{Ca}$ and $\mathrm{P}$ levels found in the two formulation samples were $0.499 \& 0.715 \%$ and $0.753 \& 0.963 \%$, respectively. As far as the samples' safety parameters are concerned, the average mc $\& a_{\mathrm{w}}$ obtained were $12.30 \% \& 0.66 \%$ for corn, $9.77 \% \& 0.64$ for rice meal and $12.93 \% \& 0.67 \%$ for soybean meal. In addition to this, the moisture levels found were high enough for fungi proliferation and mycotoxin production. 10\% of samples showed some contamination by mycotoxins (AFLs and ZON). OTA and EST were not found in any of the tests performed (LOD: $1 ;$ LOQ: $2 \mu \mathrm{g} / \mathrm{kg}$ ). Our results demonstrated that small farms are able to produce animal feed within the recommended nutritional standards. However, the implementation of quality assurance practices, to prevent nutritional fluctuations are necessary and can contribute to improving the production process and then enhancing its profitability.

Keywords: nutritional quality, feed, protein, carbohydrates, lipids, mycotoxins, swine.

\section{Avaliação da qualidade nutricional e segurança alimentar de ingredientes e rações fornecidos para suínos gestantes e leitões}

\section{Resumo}

A avaliação da composição nutricional e da segurança alimentar de rações é de fundamental importância, pois a alimentação representa uma vasta percentagem dos custos da produção animal. Mudanças na composição podem alterar o metabolismo, reduzir a capacidade digestiva e crescimento, afetando o desempenho animal e a lucratividade, o que pode ser muito crítico, especialmente em pequenas propriedades rurais. Neste trabalho nós avaliamos a qualidade nutricional [proteínas, lipídeos, carboidratos, fibra, cálcio ( $\mathrm{Ca}$ ) e fósforo $(P)$ ] e a segurança alimentar [micotoxinas, umidade $(\mathrm{mc})$ e atividade 
de água $\left(a_{w}\right)$ ] de ingredientes e rações fornecidos para suínos gestantes e leitões de uma pequena propriedade rural do Sul do Brasil. Com relação à qualidade nutricional, os dados obtidos demonstraram que farelo de soja, farelo de arroz e milho apresentam, em média, $46.35 \%, 13.94 \%$ e $8.88 \%$ de proteína, respectivamente. Com relação a fatores antinutricionais, o nível de urease presente no farelo de soja usado para alimentar suínos foi de $0.03 \%$ (0.01 a 0.09). Para as duas diferentes formulações de rações analisadas, os valores de fibra obtidos foram de $1.74 \%$ e $2.14 \%$ para leitões e animais em gestação, respectivamente. Os níveis de $\mathrm{Ca}$ e $\mathrm{P}$ encontrados nestas duas formulações de rações foram de 0.499 e $0.715 \%$ e de 0.753 e $0.963 \%$, respectivamente. Os parâmetros da segurança alimentar foram avaliados quantificando-se a mc e $a_{\mathrm{w}}$. Os dados obtidos revelaram níveis de mc e $a_{\mathrm{w}}$ de $12.30 \%$ e $0.66 \%$ para milho, $9.77 \%$ e 0.64 para farelo de arroz e $12.93 \%$ e $0.67 \%$ para farelo de soja. Os níveis de mc encontrados foram altos o suficiente para poder induzir proliferação de fungos e produção de micotoxinas. $10 \%$ das amostras apresentaram contaminação por micotoxinas (AFLs e ZON), sendo que OTA e EST não foram encontradas em nenhuma das amostras analisadas (LOD: 1 ; LOQ: $2 \mu \mathrm{g} / \mathrm{kg}$ ). Nossos resultados demonstraram que pequenas propriedades são capazes de produzir ração animal respeitando os padrões nutricionais recomendados. Porém, a implementação de práticas de qualidade e segurança alimentar com o intuito de prevenir variações nutricionais são necessárias, as quais podem contribuir para melhorar o processo de produção e, consequentemente, aumentar a lucratividade.

Palavras-chaves: qualidade nutricional, alimentação, proteína, carboidratos, lipídeos, micotoxinas, suínos

\section{INTRODUCTION}

Swine growth performance depends upon numerous factors including genetics, management practices, health status and type of diet (Kil and Stein, 2010). Swine production reached about 100 million tons worldwide and Brazil is one of 
the world's largest producers (ABIPECS, 2012). Swine feed accounts for the highest cost of the swine production system (Landero et al., 2011) and its nutritional requirements vary according to the genetic potential, age, sex and weight of the animal.

Ingredients used in feed, such as corn, are considered excellent sources of metabolized energy for swine (Yong et al., 2010; Prandini et al., 2011). Likewise, soybean meal is the main source of vegetable protein used in animal feed (Jezierny et al., 2010; Song et al., 2010). Despite being high in protein, soybean meal has antinutritional factors such as trypsin inhibitors, which may alter the digestive process and affect animal growth. These pernicious effects can be eliminated by heat and can be measured the enzyme urease assessment. Fibre-rich feed prevents gastric lesions. Minerals generally constitute 4 to $6 \%$ of animal body and calcium ( $\mathrm{Ca}$ ) and phosphorus (P), apart from being important for their bone structure, can boost the immune system and, thus, improve the animal's health.

Therefore, the quality of ingredients used in feed processing can significantly affect the quality of pork at the end of the production chain. Alteration in the feed's chemical composition, the presence of fungi and/or mycotoxins can affect animal metabolism, interfere with the digestive process and affect animal development and health. Animal nutrition has a major impact on the lipid levels found in pork (Alonso et al., 2010). Much research has been conducted to evaluate the impact of a wide range of feed ingredients and feed additives on various aspects of gut health and development in swine (Lange et al., 2010). However, little is known about the actual quality of the ingredients that are purchased by small swine producing farms from feed suppliers or of the quality and safety of feed prepared on their premises.

The aim of this study is to evaluate the quality and safety of feed ingredients and final products for pregnant (gilt/sow) and piglets in a small swine producing farm from Southern Brazil over a period of 7 months 


\section{MATERIALS AND METHODS}

Samples: Two types of swine feed samples were collected for analysis feed ingredients (grain: corn; meal: soybeans and rice) used feed final products for pregnant swine (gilts/sows) and piglets from a small farm, located in Southern Brazil. Table 1 shows the swine daily feeding routine.

Reagents, solvents and standards: Reagents - ammonium molybdate vanadate, ammonium oxalate, ammonium sulphate, celyte, copper carbonate, copper sulphate, ferric chloride, methyl red, orthophosphate, potassium chloride, potassium sulphate, potassium permanganate, sodium hydroxide, oxalic acid, sulfuric acid, formic acid, chloric acid and acetic acid, all from Vetec (Rio de Janeiro, Brazil); solvents - acetone, chloroform, ethyl acetate, methanol, and toluene, all from Carlo Erba (Milano, Italy); standards: AFLs $\left(A F B_{1}, A F B_{2}, A F G_{1}\right.$ and $\left.A F G_{2}\right), Z O N, E S T$ and OTA, all from Sigma (Steinheim, Germany).

Table 1. Swine daily feeding routine

\begin{tabular}{|c|c|c|c|c|c|c|}
\hline \multirow[b]{2}{*}{ Feed type } & \multicolumn{2}{|c|}{ Feeding } & \multicolumn{4}{|c|}{ Feed composition (\%) } \\
\hline & $\begin{array}{l}\text { Quantity } \\
\text { (kg) }\end{array}$ & $\begin{array}{c}\text { Periodicity } \\
\text { (times per } \\
\text { day) }\end{array}$ & Corn & $\begin{array}{c}\text { Soybean } \\
\text { meal }\end{array}$ & $\begin{array}{l}\text { Rice } \\
\text { meal }\end{array}$ & Other ${ }^{*}$ \\
\hline \multicolumn{7}{|l|}{ Pregnant } \\
\hline Gilts & 2.5 & 2 & 65 & 16 & 15 & 4 \\
\hline Sows & 2.5 & 2 & 65 & 16 & 15 & 4 \\
\hline \multicolumn{7}{|l|}{ Off-springs } \\
\hline Piglets & 1.0 & all the time & 60 & 29 & 5 & 6 \\
\hline
\end{tabular}


Sample collection and preparation: Collection - samples were collected from August 2010 to February 2011 in a small farm located in Santa Catarina state, Southern Brazil, at Doutor Pedrinho town. They were collected from silos (stored in bulk/loose) and storehouses (stored in bags). Corn and soybean meal were collected from silos of 50 and 20 ton capacity, respectively. Rice meal from local suppliers and feed for pregnant swine and piglets prepared on the premises were collected from $25 \mathrm{~kg}$ bags. $200 \mathrm{~g}$ of each sample type were gathered from different collection points to get a total sample of $1 \mathrm{~kg}$ (composite sample) of each ingredient and feed (Figure 1). Preparation - each sample was homogenized and divided into smaller portions (analytical samples) for analysis of proximate composition (lipids, fibre, ash, protein, $\mathrm{Ca}$, P), mc, $a_{w}$, urease and mycotoxins (AFLs, ZON, EST and OTA).

Evaluation of swine feed nutritional quality: analysis of lipids, fibre, $\mathrm{Ca}, \mathrm{P}$, ash and urease activity were performed according to standard number 108 of the Ministry of Agriculture of Brazil - MAPA (Brazil, 1993). Protein and mc analyses were performed by the AOAC method (2005). Protein: analysed by sample digestion with sulphuric acid catalysed by copper sulphate and potassium sulphate to accelerate the reaction. A portion of the sample was transferred to Kjeldahl flask with catalyst mixture and sulphuric acid. The sample was cooled and, after addition of water and sodium hydroxide, was distilled. Next, distilled water and sulphuric acid were added. Excess acidity was corrected with sodium hydroxide solution (AOAC, 2005). 


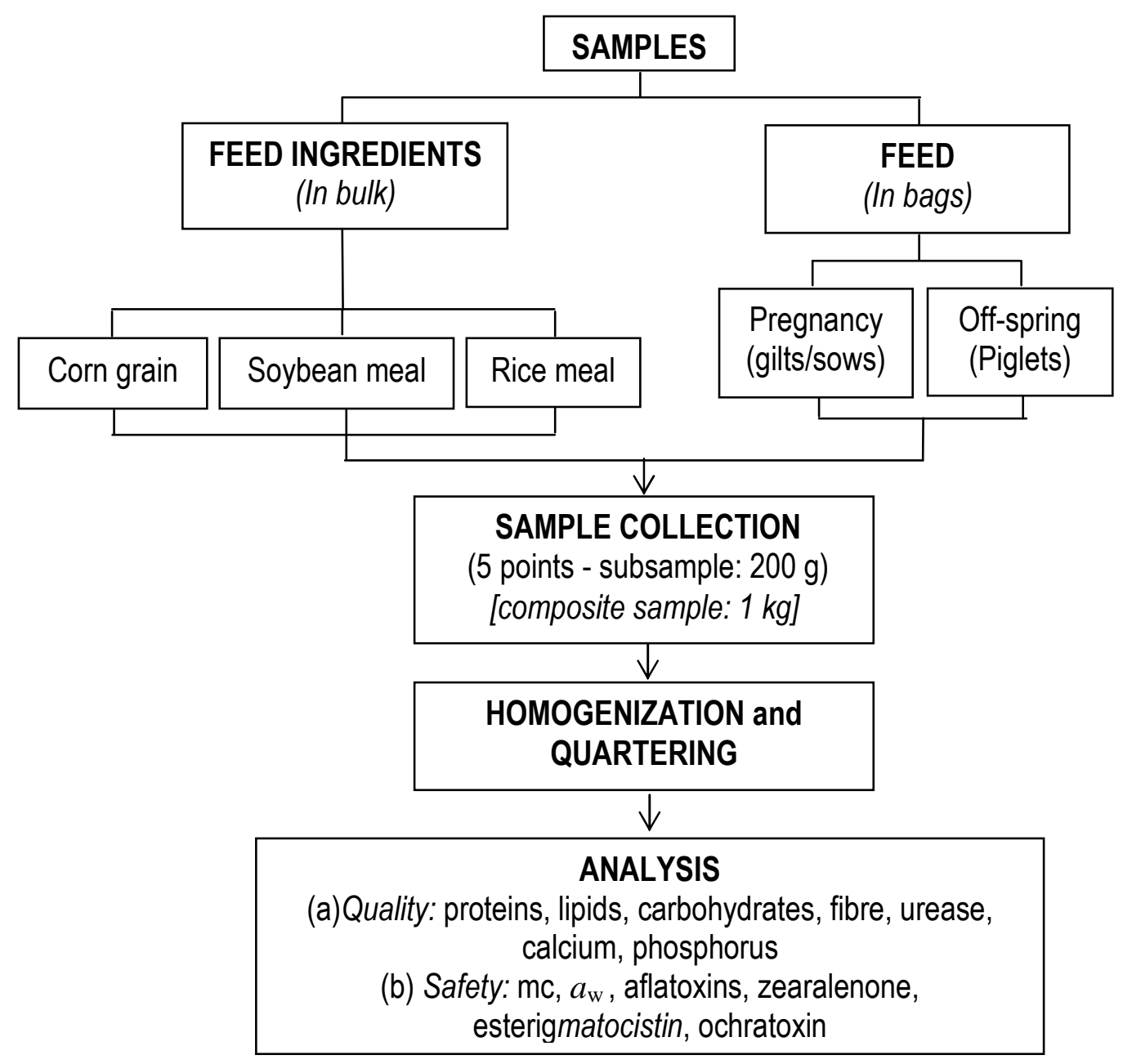

Figure 1. Flowchart of swine ingredients and feed sample collection and analysis

Carbohydrate: carbohydrate content was obtained by subtracting the sum of the contents of proteins, lipid, fibre, $\mathrm{mc}$ and ash from one hundred. Lipids: the fraction extraction was performed by vapour drag. The sample was transferred to a cartridge extractor and dried at $105^{\circ} \mathrm{C}$. The condenser was adjusted and sufficient amount of solvent was kept throughout the process. Calculations were based on the difference in weight and percentage (Brazil, 1993). Fibre: determined by analysing the insoluble organic residue of the sample, after acid (sulfuric acid) and alkaline (sodium hydroxide) digestion. Performed by a reflux system, filtration (vacuum in a Buchner funnel) and incineration in a muffle $\left(550^{\circ} \mathrm{C}\right)$. Calculations were performed as suggested by MAPA (Brazil, 1993). 
Ash: the method is based on the elimination of volatile organic and inorganic matter at a high temperature $\left(550\right.$ to $\left.600^{\circ} \mathrm{C}\right)$. The residue is called ash. The percentage of ash is calculated by the difference in sample weight, before and after three hour incineration, (Brazil, 1993)

Calcium: the analysis was based on the precipitation of $\mathrm{Ca}$ from the solution obtained from the ashes of the sample in the presence of ammonium oxalate. The resulting precipitate (Ca oxalate) is dissolved in chloric acid to form oxalic acid, which is analysed by oximetry (through titration with sulfuric acid, potassium permanganate and methyl red). Phosphorus: the amount of $P$ determinant by colorimetry. From a reaction of the acid solution of orthophosphate with ammonium molybdate vanadate, a yellow complex is formed, which is measured colorimetrically. The absorbance was compared to a standard curve previously prepared (Brazil, 1993). Urease activity: calculated by observation of $\mathrm{pH}$ variation, resulting from the ammonia released by the enzymatic action of urease (Brazil, 1993).

Evaluation of swine feed safety: Determinations of AFLS, OTA, ZON and EST: was performed by the method described by Soares and Rodrigues-Amaya (1989). Briefly, each sample was extracted with methanol and potassium chloride (4\%), filtered and, after that, ammonium sulphate (30\%) was added, followed by moderate stirring and filtration. The resulting filtrate was transferred to a separation funnel, and toxins were extracted with chloroform. Extracts were collected in a beaker and submitted to solvent evaporation. Extracts were re-suspended in $200 \mu \mathrm{L}$ of toluene and immediately subjected to thin layer chromatography. The analyses was performed in cuba saturated with the following solvent system: toluene - ethyl acetate - formic acid $(60: 40: 0.5)$. The toxins were detected under UV light and quantified by comparation to toxin standards ( $\lambda: 256 \& 365 \mathrm{~nm}$ ). The limits of quantification (LOQ) and determination (LOD) were 2 and $1 \mu \mathrm{g} / \mathrm{L}$, respectively. Moisture content: performed according to AOAC (2005), which consists of drying the 
sample in an oven at $110^{\circ} \mathrm{C}\left( \pm 5^{\circ} \mathrm{C}\right)$. Water activity: determination was carried out by the Aqualab 4 method.

Statistic analysis: performed by variance analysis (ANOVA) and Turkey's test, to evaluate significant differences among the means of $\mathrm{Ca}, \mathrm{P}$ and urease activity $(P<0.05)$ using GraphPad Prism 4.0 software. The results were expressed as the mean values and standard errors.

\section{RESULTS AND DISCUSSION}

The data obtained showed that the nutritional quality and safety of feed ingredients and final products (for pregnant swine and piglets), used for feeding swine in a small farm in Southern Brazil, showed little variation over the standards established by NRC (1998) and Rostagno (2011). The quality (proximate composition, sample collection details, feed formulation standards) and the safety (mycotoxins, $\mathrm{mc}$ and $a_{\mathrm{w}}$ ) data are shown in Tables 2 and 3. 
NONES, J. et al. Nutritional quality and safety assessment of ingredients and feed given to pregnant swine and piglets. PUBVET, Londrina, V. 6, N. 27, Ed. 214, Art. 1426, 2012.

Table 2. Ingredients proximate composition used for swine feed formulation

\begin{tabular}{|c|c|c|c|c|c|c|c|c|c|c|}
\hline \multirow{2}{*}{$\begin{array}{c}\text { Feed } \\
\text { Ingredient }\end{array}$} & \multirow{2}{*}{$\begin{array}{c}\text { Number of } \\
\text { samples }\end{array}$} & \multirow[b]{2}{*}{ Protein } & \multicolumn{5}{|c|}{ Composition (\%) } & \multicolumn{3}{|c|}{ Collection date } \\
\hline & & & Carbohydrate & Lipids & Fibre & Ashes & Mc & $a_{w}$ & Month & Year \\
\hline \\
\hline & 12 & 8.27 & 74.41 & 2.64 & 1.47 & 1.14 & 12.07 & 0.67 & Aug & 2010 \\
\hline & & 8.03 & 73.21 & 3.09 & 1.57 & 0.98 & 13.12 & 0.64 & Aug & \\
\hline & & 7.80 & 73.75 & 3.53 & 1.48 & 1.13 & 12.31 & 0.71 & Sept & \\
\hline & & 8.00 & 73.69 & 3.76 & 1.13 & 1.08 & 12.34 & 0.66 & Sept & \\
\hline & & 8.11 & 74.57 & 3.82 & 0.68 & 1.08 & 11.74 & 0.69 & Oct & \\
\hline & & 7.99 & 76.09 & 3.68 & 0.83 & 0.96 & 10.45 & 0.69 & Nov & \\
\hline & & 7.86 & 74.94 & 3.90 & 0.53 & 1.23 & 11.54 & 0.63 & Nov & \\
\hline & & 7.66 & 73.20 & 3.69 & 0.78 & 1.03 & 13.64 & 0.69 & Dec & \\
\hline & & 7.37 & 74.19 & 3.34 & 1.45 & 1.14 & 12.51 & 0.65 & Dec & \\
\hline & & 20.22 & 56.25 & 3.64 & 1.09 & 6.24 & 12.56 & 0.60 & Jan & 2011 \\
\hline & & 7.83 & 73.92 & 3.41 & 1.34 & 1.12 & 12.38 & 0.67 & Jan & \\
\hline & & 7.41 & 73.80 & 3.64 & 1.12 & 1.09 & 12.94 & 0.67 & Feb & \\
\hline & Average: & 8.88 & 72.67 & 3.51 & 1.12 & 1.52 & 12.30 & 0.66 & NA & \\
\hline & Max: & 20.22 & 76.09 & 3.90 & 1.57 & 6.24 & 13.64 & 0.71 & NA & \\
\hline & Min: & 7.37 & 56.25 & 2.64 & 0.53 & 0.96 & 10.45 & 0.60 & NA & \\
\hline & Standard & $7.9-8.3$ & NS & $3.6-3.9$ & 1.7 & 1.3 & NS & NS & NA & \\
\hline \multicolumn{11}{|l|}{ Rice } \\
\hline & 12 & 14.13 & 44.50 & 17.99 & 6.03 & 8.21 & 9.14 & 0.68 & Aug & 2010 \\
\hline & & 13.28 & 40.15 & 20.38 & 7.49 & 8.94 & 9.76 & 0.61 & Aug & \\
\hline & & 14.13 & 40.11 & 19.81 & 8.18 & 7.98 & 9.79 & 0.68 & Sept & \\
\hline & & 14.34 & 36.68 & 21.35 & 7.20 & 8.23 & 9.26 & 0.68 & Sept & \\
\hline & & 13.33 & 42.24 & 15.38 & 8.69 & 9.59 & 10.77 & 0.64 & Oct & \\
\hline & & 14.25 & 38.83 & 20.72 & 7.45 & 9.02 & 9.73 & 0.69 & Nov & \\
\hline & & 12.87 & 42.57 & 22.08 & 5.91 & 7.97 & 8.60 & 0.68 & Nov & \\
\hline & & 12.20 & 46.18 & 16.65 & 7.21 & 7.32 & 10.44 & 0.66 & $\mathrm{Dec}$ & \\
\hline & & 14.07 & 40.40 & 21.60 & 5.95 & 8.12 & 9.86 & 0.63 & Dec & \\
\hline & & 14.14 & 36.38 & 22.24 & 8.13 & 8.84 & 10.27 & 0.54 & Jan & 2011 \\
\hline & & 15.36 & 35.20 & 23.16 & 6.76 & 10.02 & 9.50 & 0.58 & Jan & \\
\hline & & 15.13 & 36.68 & 21.86 & 6.04 & 10.23 & 10.06 & 0.66 & Feb & \\
\hline & Average: & 13.94 & 39.99 & 20.27 & 7.09 & 8.71 & 9.77 & 0.64 & NA & \\
\hline & Max: & 15.36 & 46.18 & 23.16 & 8.69 & 10.23 & 10.77 & 0.69 & NA & \\
\hline & Min: & 12.20 & 35.20 & 15.38 & 5.91 & 7.32 & 8.60 & 0.54 & NA & \\
\hline & Standard & $13.1-13.3$ & NS & $13-14.5$ & 8.1 & 9.0 & NS & NS & NA & \\
\hline \multicolumn{11}{|l|}{ Soybean } \\
\hline & 12 & 44.06 & 31.82 & 2.29 & 3.32 & 6.03 & 12.48 & 0.70 & Aug & 2010 \\
\hline & & 47.14 & 26.56 & 2.94 & 3.54 & 5.67 & 14.15 & 0.66 & Aug & \\
\hline & & 46.86 & 27.54 & 3.09 & 3.49 & 5.68 & 13.34 & 0.70 & Sept & \\
\hline & & 46.94 & 28.82 & 2.76 & 3.68 & 5.86 & 11.94 & 0.69 & Sept & \\
\hline & & 45.86 & 28.48 & 2.42 & 3.56 & 5.94 & 13.74 & 0.65 & Oct & \\
\hline & & 46.23 & 29.67 & 1.81 & 4.29 & 6.05 & 11.95 & 0.67 & Nov & \\
\hline & & 47.15 & 28.83 & 1.72 & 4.11 & 6.25 & 11.94 & 0.67 & Nov & \\
\hline & & 46.83 & 27.99 & 1.90 & 3.45 & 6.11 & 13.72 & 0.69 & Dec & \\
\hline & & 46.30 & 27.75 & 3.27 & 4.15 & 5.89 & 12.64 & 0.69 & Dec & \\
\hline & & 45.22 & 29.52 & 2.93 & 3.64 & 5.74 & 12.95 & 0.63 & Jan & 2011 \\
\hline & & 46.52 & 27.09 & 3.03 & 3.72 & 5.99 & 13.65 & 0.66 & Jan & \\
\hline & & 47.14 & 29.00 & 1.97 & 3.33 & 5.93 & 12.63 & 0.68 & Feb & \\
\hline & Average: & 46.35 & 28.59 & 2.51 & 3.69 & 5.93 & 12.93 & 0.67 & NA & \\
\hline & Max: & 47.15 & 31.82 & 3.27 & 4.29 & 6.25 & 14.15 & 0.70 & NA & \\
\hline & Min: & 44.06 & 26.56 & 1.72 & 3.32 & 5.67 & 11.94 & 0.63 & NA & \\
\hline & Standard & $44-45$ & NS & $1.5-1.7$ & 5.3 & 5.8 & NS & NS & NA & \\
\hline
\end{tabular}

Total general: 36

NA: not applicable; NS: not specified; Standard: Rostagno (2011) and NRC (1998) 
NONES, J. et al. Nutritional quality and safety assessment of ingredients and feed given to pregnant swine and piglets. PUBVET, Londrina, V. 6, N. 27, Ed. 214, Art. 1426, 2012.

Table 3. Proximate composition of feed for pregnant swine and piglets

\begin{tabular}{|c|c|c|c|c|c|c|c|c|c|c|}
\hline \multirow{2}{*}{ Feed } & \multirow{2}{*}{$\begin{array}{c}\text { Number of } \\
\text { samples }\end{array}$} & \multicolumn{6}{|c|}{ Composition (\%) } & \multirow[b]{2}{*}{$a_{w}$} & \multicolumn{2}{|c|}{ Collection date } \\
\hline & & Protein & Carbohytrates & Lipids & Fibre & Ashes & Mc & & Month & Year \\
\hline \multicolumn{11}{|c|}{ Pregnancy } \\
\hline & \multirow[t]{12}{*}{12} & 16.53 & 61.97 & 1.01 & 2.04 & 6.55 & 11.90 & 0.92 & Aug & 2010 \\
\hline & & 14.60 & 58.44 & 5.61 & 2.50 & 6.31 & 12.54 & 0.68 & Aug & \\
\hline & & 14.84 & 61.89 & 3.76 & 1.99 & 5.28 & 12.24 & 0.76 & Sept & \\
\hline & & 15.48 & 61.35 & 5.04 & 1.80 & 5.09 & 11.24 & 0.72 & Sept & \\
\hline & & 14.83 & 61.08 & 4.98 & 1.99 & 5.43 & 11.69 & 0.65 & Oct & \\
\hline & & 14.81 & 60.28 & 5.98 & 2.04 & 5.60 & 11.29 & 0.68 & Nov & \\
\hline & & 14.81 & 61.54 & 5.88 & 1.89 & 5.27 & 10.61 & 0.66 & Nov & \\
\hline & & 15.00 & 58.66 & 5.46 & 2.54 & 5.70 & 12.64 & 0.68 & Dec & \\
\hline & & 14.13 & 59.04 & 5.85 & 2.63 & 5.44 & 12.91 & 0.67 & Dec & \\
\hline & & 15.18 & 59.96 & 6.02 & 1.90 & 5.61 & 11.33 & 0.55 & Jan & 2011 \\
\hline & & 14.84 & 59.84 & 6.10 & 1.81 & 5.62 & 11.79 & 0.62 & Jan & \\
\hline & & 16.33 & 58.87 & 5.19 & 2.57 & 5.19 & 11.85 & 0.67 & Feb & \\
\hline & Average: & 15.12 & 60.24 & 5.07 & 2.14 & 5.59 & 11.84 & 0.68 & NA & \\
\hline & Max: & 16.53 & 61.97 & 6.10 & 2.63 & 6.55 & 12.91 & 0.92 & NA & \\
\hline & Min: & 14.13 & 58.44 & 1.01 & 1.80 & 5.09 & 10.61 & 0.55 & NA & \\
\hline \multicolumn{11}{|c|}{ Off-spring } \\
\hline & \multirow[t]{12}{*}{12} & 25.40 & 54.73 & 0.60 & 1.60 & 5.68 & 11.99 & 0.91 & Aug & \multirow[t]{12}{*}{2010} \\
\hline & & 20.89 & 58.07 & 2.62 & 1.72 & 4.73 & 11.97 & 0.64 & Aug & \\
\hline & & 19.78 & 58.81 & 2.63 & 1.59 & 4.32 & 12.87 & 0.74 & Sept & \\
\hline & & 20.97 & 57.78 & 3.24 & 1.80 & 4.27 & 11.94 & 0.69 & Sept & \\
\hline & & 18.78 & 58.19 & 2.30 & 1.73 & 4.96 & 14.04 & 0.73 & Oct & \\
\hline & & 20.58 & 58.87 & 3.18 & 1.54 & 4.31 & 11.52 & 0.68 & Nov & \\
\hline & & 19.65 & 59.91 & 3.41 & 1.89 & 4.41 & 10.73 & 0.65 & Nov & \\
\hline & & 19.38 & 57.61 & 3.66 & 1.81 & 4.44 & 13.10 & 0.68 & Dec & \\
\hline & & 20.13 & 57.30 & 3.10 & 2.18 & 4.77 & 12.52 & 0.66 & Dec & \\
\hline & & 20.54 & 57.65 & 3.73 & 1.62 & 4.55 & 11.91 & 0.59 & Jan & \\
\hline & & 20.50 & 57.98 & 3.34 & 1.65 & 4.49 & 12.04 & 0.65 & Jan & \\
\hline & & 19.63 & 58.50 & 3.53 & 1.80 & 4.40 & 12.14 & 0.66 & Feb & \\
\hline & Average: & 20.52 & 57.95 & 2.95 & 1.74 & 4.61 & 12.23 & 0.69 & NA & \\
\hline & Max: & 25.40 & 59.91 & 3.73 & 2.18 & 5.68 & 14.04 & 0.91 & NA & \\
\hline & Min: & 18.78 & 54.73 & 0.60 & 1.54 & 4.27 & 10.73 & 0.59 & NA & \\
\hline
\end{tabular}

NA: not applicable; NS: not specified

\section{Ingredient and feed proximate composition}

Protein: The protein content of the soybean meal samples evaluated ranged from 44.06 to $47.15 \%$. Those values were higher than those reported for protein by Karr-Lilienthal (2005) (29.0 to $42.2 \%$ ). The protein content of rice meal samples was lower than that of soybean (12.20 to 15.36). These values are in agreement with those published by Huang (2005), which reported crude protein values from 15.7 to $17.2 \%$ for rice meal. The protein content of corn samples ranged from 7.37 to $20.22 \%$. Corn contains a relatively low 
concentration of protein (8\%) compared with wheat and barley (11\%) (Cowieson et al., 2005). The values for protein found in all ingredients (corn, soybean and rice meal) were in agreement with NRC (1998) and Rostagno (2011), with the sole exception of one corn sample that showed a higher protein content.

Carbohydrates: Of the feed ingredients evaluated, soybean meal showed an average carbohydrate content of $28.59 \%$ followed by rice meal with $39.99 \%$ and corn with $72.67 \%$, values that are in agreement with those reported in the literature (Karr-Lilienthal et al., 2005; Amissah et al., 2003; Kereliuk et al., 1995). Only one corn sample showed $56.25 \%$ of carbohydrate, which is lower than the average (76.8\%), proposed by Kereliuk (1995).

Lipids: the lipid content of corn samples ranged between 2.64 and 3.90, lower than found by Aisha (2004) (from 4.9 to $6.2 \%$ ). This may reflect factors such as: corn variety, growing conditions, drying temperature, starch structure, lipid starch matrices and the presence of various anti-nutritive factors (Cowieson et al., 2005). The lipid content in rice meal samples ranged from 15.38 to 23.16 , values similar to those reported by Huang (2005)(23.3 to 24.9\%). However, they are higher than those recommended by NRC (1998) and Rostagno (2011). The lipid content found in soybean meal ranged from 1.72 to $3.27 \%$. Feed for pregnant swine had higher lipid content $(5.07 \%)$ than that of piglets (2.95\%).

Fibre: corn samples had the lowest amount of crude fibre (1.12\%). Soybean meal also showed low fibre content, averaging $3.69 \%$. Rice meal showed the highest values averaging $7.09 \%$. Fibre content values were lower than recommended in corn, rice meal and in soybean samples (NRC, 1998; Rostagno, 2011). Fibre values obtained for pregnant swine and piglets were $2.14 \%$ and $1.74 \%$, respectively.

Ash: The average ash content value for rice meal was $8.71 \%$, similar to that found by Huang (2005), (9.2 to $11.3 \%$ ). Corn and soybean meal samples showed lower values, ranging from 0.96 to 6.24 and 5.67 to 6.25 , respectively. Piglet feed had a lower percentage $(4.61 \%)$ of ash in relation to 
pregnant swine feed $(5.59 \%)$, which is consistent with the different metabolic needs of the animals. Nutrient requirements (per unit of diet) of $P$, decreases with increasing age and body weight (NRC, 1998). The average content of $P$ was found to be 0.499 and $0.715 \%$ for piglets and pregnant swine feed, respectively (Figure 2, a). Dietary $\mathrm{P}$ deficiencies not only affect growth, but also adversely affect bone mineralisation (Varley et al., 2011). The average content of Ca was found to be 0.753 and $0.963 \%$ for piglets and pregnant swine feed, respectively (Figure $2, \mathrm{~b}$ ). The values of $\mathrm{P}$ and $\mathrm{Ca}$ found match the requirements considered ideal for these life stages of the animals (NRC, 1998).
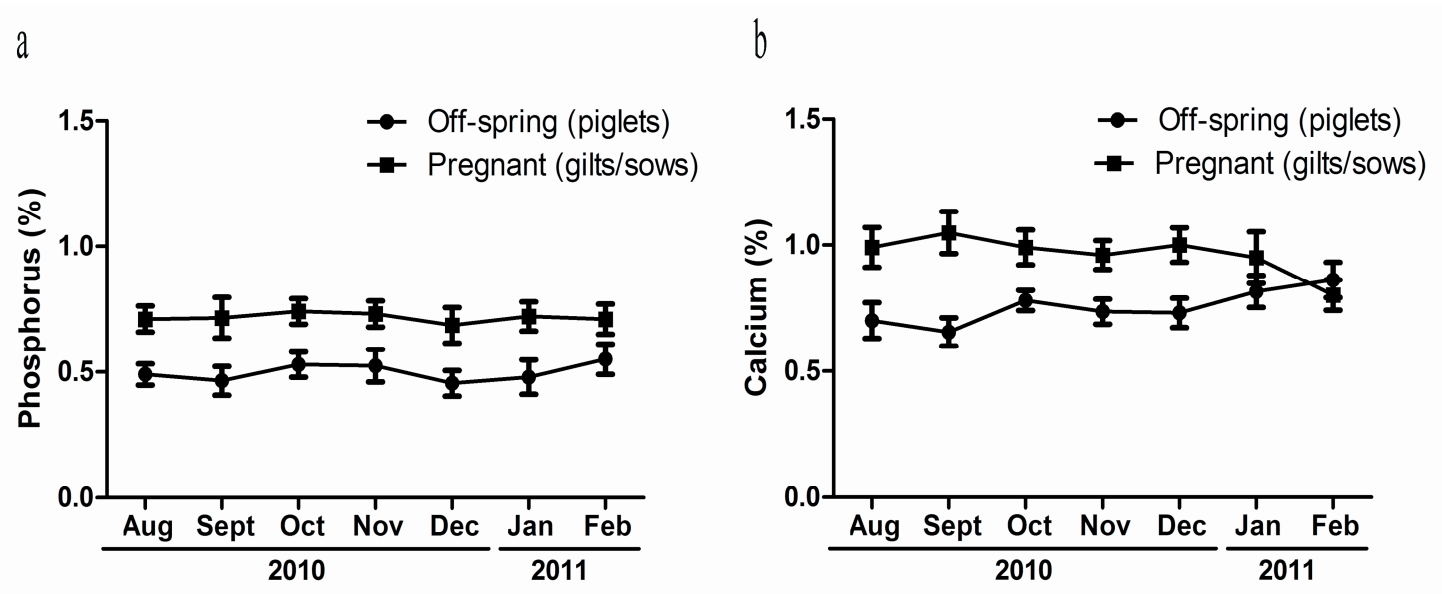

Figure 2. Average of (a) phosphorus and (b) calcium levels detected in feed for piglets and pregnant swine $(\mathrm{P}>0.05)$.

Urease: urease activity in soybeans can detect the presence of toxic factors such as trypsin inhibitors (White et al., 2000). The urease activity of soybeans in the current study ranged from 0.01 to 0.09 , with and average of 0.03 (Figure 3). The values found were in agreement with Drew (2007) who considered an urease activity of 0.05 to 0.30 as ideal. 


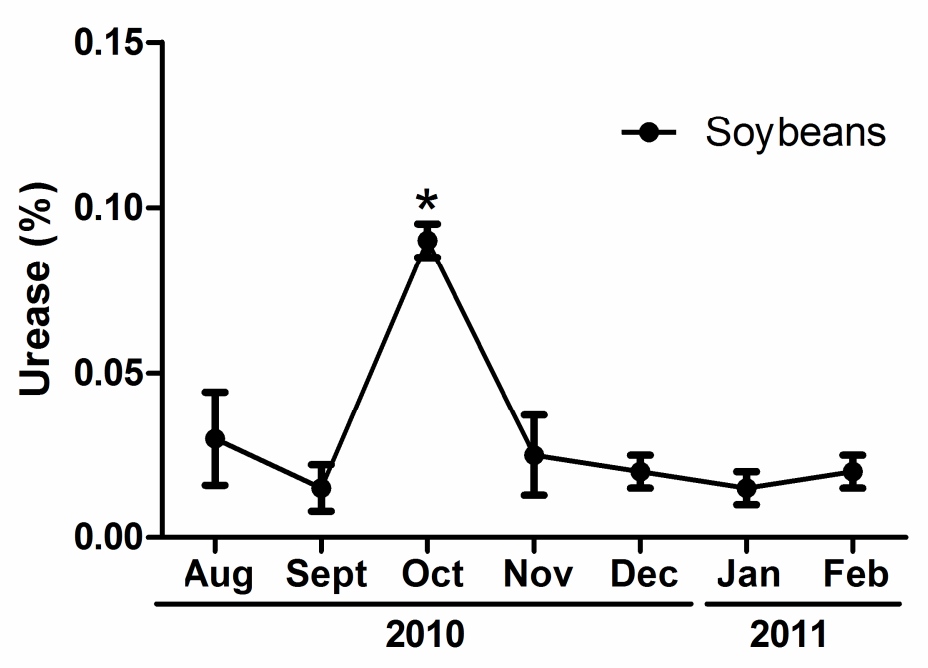

Figure 3. Urease activity of soybean samples $(* P<0.05)$.

\section{Ingredients and swine feed safety}

Mc and aw: high mc grains can be stored with maintenance of the nutrient content (Pieper et al., 2011). However, excess mc may facilitate the spread of fungi and thus lead to the development of mycotoxins that could harm livestock. The mc levels of samples were $9.77,12.30,12.93 \%$, for rice meal, corn and soybeans meal, respectively. Samples of feed for piglets and pregnant swine showed mc 12.23 and $11.84 \%$, respectively. Our data showed an mc value above the ideal, which may contribute to the presence of mycotoxins in feed and consequent generation of health problems. According to Scussel et al (2002), mc should be below $12 \%$ for grains to prevent the proliferation of fungi and production of mycotoxins.

Regarding $a_{\mathrm{w}}$, feed for piglets and pregnant swine displayed mean values of 0.69 and 0.68 , respectively. The values were similar to those found by Rosa et al. (2009) (0.628). Of the 60 samples analysed, only four $(6.66 \%)$ presented $a_{\mathrm{w}}$ lower than 0.6 (minimum $a_{\mathrm{w}}$ limit for fungi growth). Two samples showed values of $a_{w}$ greater than 0.9. No significant quantities of mycotoxins are produced for $a_{\mathrm{w}}$ below 0.95 (Nielsen, 2003). 
Mycotoxin: of the total number of samples analysed, $5(8.33 \%)$ presented some AFLs contamination [rice meal (1), corn (1) off-spring feed (3)] and only one (pregnancy feed, $64.10 \mu \mathrm{g} / \mathrm{kg}$ ) by ZON. The levels of AFLs presented in samples were $83.33,34.52$ and $49.31 \mu \mathrm{g} / \mathrm{kg}$ for rice meal, corn, off-spring feed, respectively. Pereyra et al. (2008) reported $33.33 \%$ of AFLs contamination in samples of swine feed at levels of 30 to $70 \mu \mathrm{g} / \mathrm{kg}$. In the present study, $25 \%$ of samples had AFLs contamination, at levels between 182 and $311 \mu \mathrm{g} / \mathrm{kg}$. Other studies also reported some contamination by AFLs, OTA e ZON in swine feed (Thieu et al., 2008; Rosa et al., 2009). EST and OTA were not found in any of the samples analysed. The ingredients and swine feed were compared against existing regulations of Chile, United State of America, Estonia and Mexico, which tolerate levels of AFLs contamination of 100-300 $\mu \mathrm{g} / \mathrm{kg}$ (FAO, 2004). Likewise, the ingredients and feed were considered safe, due to the absence of OTA and ZON values below those recommended by international legislation (maximum levels for OTA and ZON are $20-2000 \mu \mathrm{g} / \mathrm{kg}$ e 20-3000 $\mu \mathrm{g} / \mathrm{kg}$, respectively) (FAO, 2004).

\section{CONCLUSION}

Although most of the nutrient data obtained in this work were in accordance with the standards established in Brazil (Rostagno, 2011) and in the rest of the world (NRC, 1998), some of them were not in accordance with recommended levels (fibre and lipids). We must consider that the chemical and nutritional constituents of animal feeds are important for livestock nutrition and growth, but are only part of the animal feed matrix. Other points relating to management, genetics and animal health must be taken into consideration. The presence of mycotoxin in feed requires periodic monitoring in order to prevent the occurrence of mycotoxicosis in animal production, and thus reducing economic losses and minimizing hazards to swine health. Small farms are capable of producing animal feed within the recommended nutritional standards. However, the implementation of quality assurance practices, aimed 
NONES, J. et al. Nutritional quality and safety assessment of ingredients and feed given to pregnant swine and piglets. PUBVET, Londrina, V. 6, N. 27, Ed. 214, Art. 1426, 2012.

at preventing nutritional fluctuations, is highly recommended. The emergence of laws aimed at standardizing the specific nutritional values of these foods may be alternatives to improve production and profitability

\section{REFERENCES}

ABIPECS. 2012. Associação Brasileira da Indústria Processadoras e Exportadoras de Carne Suína. Online www.abipecs.org.br.

Aisha, S. M. F. and El Tinay, A.H. 2004. Effect of genotype, malt pre-treatment and cooking on in vitro protein digestibility and protein fractions of corn. Food Chem. 84: 613619.

Alonso, V., Campo, M. M., Provincial, L., Roncalés, P. and Beltrán, J. A. 2010. Effect of protein level in commercial diets on pork meat quality. Meat Sci. 85: 714.

Amissah, J. G.N., Ellis, W. O., Oduro, I. and Manful, J. T. 2003. Nutrient composition of bran from new rice varieties under study in Ghana. Food Control. 14: 2124.

AOAC. 2005. Official Methods of Analysis of AOAC International, (18th edition), Association of Official Analytical Chemists International, Gaithersburg, MD.

Brazil. 1993. Ministério da Agricultura Pecuária e Abastecimento. Portaria No 108, de 17 de março.

Brazil. 1988. Ministério da Agricultura Pecuária e Abastecimento Portaria $\mathrm{N}^{\circ} 7$, de 9 de novembro.

Cowieson, A. J. 2005. Factors that affect the nutritional value of maize for broilers. Animal Feed Science and Tecnology. 119: 293305.

Huang, S. C., Shiau, C. Y., Liu, T. E., Chu, C. L. and Hwang, D. F. 2005. Effects of rice bran on sensory and physico- chemical properties of emulsified pork meatballs. Meat Sci. 70: 613619.

Drew, M.D., Borgeson, T.L. and Thiessen, D.L. 2007. Anim. Feed Sci. Technol.138: 118136.

FAO, 2004. Worldwide regulations for mycotoxins in food and feed in 2003. FAO Food and Nutrition paper No. 81. Food and Agriculture Organization of the United Nations, Rome, Italy.

Jezierny, D., Mosenthin, R. and Bauer, E. 2010. The use of grain legumes as a protein source in pig nutrition: A review. Anim. Feed Sci. Technol. 157: 111128.

Karr-Lilienthal $_{\perp}$ L. K., Kadzere ${ }_{\perp}$ C. T., Grieshop ${ }_{\perp}$ C. M. and Fahey ${ }_{\perp}$ G. C., 2005. Chemical and nutritional properties of soybean carbohydrates as related to non ruminants: A review. Livest Prod Sci. 97: 112.

Kereliuk, G. R., Sosulski, F. W. and Kaldy, M. S. G. 1995. Carbohydrates of North American corn (Zea mays). Food Res Int. 28: 311315. 
Kil, D.Y. and Stein, H. H. 2010. Management and feeding strategies to ameliorate the impact of removing antibiotic growth promoters from diets fed to weanling pigs. Can. J. Anim. Sci. 90: 447460 .

Landero $_{\downarrow}$ J. L., Beltranena ${ }_{\downarrow}$ E., Cervantes ${ }_{\downarrow}$ M., Morales $_{\downarrow}$ A. and Zijlstra ${ }_{\downarrow}$ R. T. 2011. The effect of feeding solvent-extracted canola meal on growth performance and diet nutrient digestibility in weaned pigs. Anim. Feed Sci. Technol. 170: 136140.

Lange $_{\perp}$ C. F. M., Pluske ${ }_{\perp}$ J., Gong $_{\star}$ J. and Nyachoti $_{+}$C. M. 2010. Strategic use of feed ingredients and feed additives to stimulate gut health and development in young pigs. Livest Sci. 134: 124134.

Nielsen, K. F 2003. Mycotoxin production by indoor molds. Fungal Gen Biol. 39: 103117.

NRC, 1998. National Research Council (NRC), 1998. Nutrient Requirements of Swine, 10th Edition. National Academy Press, Washington, DC.

Pereyra, G., Pereyra, C. M., Ramirez, M. L., Rosa, C. A. R., Dalcero, A. M. and Cavaglieri, L. R. 2008. Determination of mycobiota and mycotoxins in pig feed in central Argentine. Lett Appl Microbiol. 46: 555561.

Pieper, R., Hackl ${ }_{\perp}$ W., Korn ${ }_{\perp}$ U., Zeyner ${ }_{\perp}$ A., Souffrant, W. B. and Pieper, B. 2011. Effect of ensiling triticale, barley and wheat grains at different moisture content and addition of Lactobacillus plantarum (DSMZ 8866 and 8862) on fermentation characteristics and nutrient digestibility in pigs. Anim Feed Sci Technol. 164: 96105.

Prandini, A., Sigolo, S., Morlacchini, M., Marocco, A., Lo Pinto, M. 2011. High-protein maize in diets for growing pigs. Anim Feed Sci Technol. 165: 105110.

Rosa, C. A. R., Keller, K. M., Keller, L. A. M., Pereyra, M. L. G., Pereyra, C. M., Dalcero, A. M., Cavaglieri, L. R., Lopes, C. W. G. 2009. Mycological survey and ochratoxin A natural contamination of swine feedstuffs in Rio de Janeiro State, Brazil. Toxicon. 53: 283288.

Rostagno, H. S. 2011.Composição de Alimentos e Exigências Nutricionais 3a Edição Universidade Federal de Viçosa - Departamento de Zootecnia.

Scussel V M. 2002. Fungos em Grãos Armazenados. In: Lorini I.; Miike, L; Scussel, Vm. Armazenagem de Grãos. Ed. Biogeneziz.

Soares, L. M. V. and Rodriguez-Amaya, D. B. 1989. Survey of aflatoxins, ochratoxin A, zearalenone and sterigmatocystin in some Brazilian foods by using multi-toxin thin-layer chromatographic method. J Assoc Off Anal Chem. 72: 2226.

Song, Y. S., Pérez ${ }_{+}$V. G., Pettigrew, J. E., Martinez-Villaluenga, C., Gonzalez, E. M. 2010. Fermentation of soybean meal and its inclusion in diets for newly weaned pigs reduced diarrhea and measures of immunoreactivity in the plasma.Anim. Feed Sci Technol. 159: 4149.

Thieu, N. Q., Ogle, B. and Pettersson, H. 2008. Screening of Aflatoxins and Zearalenone in feedstuffs and complete feeds for pigs in Southern Vietnam. Trop Anim Health Prod. 40: 7783.

Varley, P. F., Callan ${ }_{\llcorner}$J. J. and O'doherty, J. V. 2011. Effect of dietary phosphorus and calcium level and phytase addition on performance, bone parameters, apparent nutrient digestibility, mineral and nitrogen utilization of weaner pigs and the subsequent effect on finisher pig bone parameters. Anim. Feed Sci. Technol. 165: 201209 
White, C. E., Campbell, D. R. and McDowell, L. R. 2000. Effects of dry matter content on trypsin inhibitors and urease activity in heat treated soya beans fed to weaned piglets. Animal feed Sci. Technol. 87: 105115.

Yong, L., Zhengfeng, F., Jinjun, D., Gary, P., Yingjun, R. and Jian, P. 2010. Corn extrusion and enzyme addition improves digestibility of corn/soy based diets by pigs: In vitro and in vivo studies. Anim. Feed Sci. Technol. 158: 146154. 